\title{
ABSTRAK \\ KEDUDUKAN ASESMEN BAGI KONSELOR PROFESIONAL
}

Oleh: Drs. Yusri, M.Pd., Kons.

Fakultas Ilmu Pendidikan (FIP) Universitas Negeri Padang

Asesmen bagi konselor bimbingan dan konseling sebagai jabatan profesional merupakan alat kerja untuk mengukur dan mengungkapkan data, keterangan dan kebutuhan siswa dalam rangka memberikan layanan konseling. Jenis asesmen dalam konseling melalui 2 (dua) bentuk atau teknik yaitu asesemen tes dan non-tes. Konselor professional diharapkan mampu mengenal, memilih,membuat/merancang, melaksanakan, dan menggunakan hasil asesmen untuk kepentingan konseling. Konselor bekerja tanpa melakukan pengukuran sebelum memberikan bantuan atau konseling dimungkinkan hasil konseling tidak sesuai dengan masalah atau kebutuhan siswa sehingga masalah siswa sebagai klien tidak terentaskan dengan baik. Penyusunan program kerja Bimbingan dan Konseling (BK) didasarkan analisis kebutuhan dari hasil asesmen, asesmen adalah suatu alat yang mampu menyumbangkan data awal dalam mengungkapkan potensi, kemampuan dan kemungkinan permasalahan siswa. Tulisan ini membahas pentingnya konselor profesional menguasai memilih, membuat, melaksanakan, mengolah, menafsirkan dan mengunakan hasil asesmen sebagai alat bekerja bagi konselor professional di lapangan baik sekolah maupun luar sekolah.

Pembahasan mengkaji tentang kedudukan asesmen dalam pelaksanaan pekerjaan konselor profesional meliputi: (1). Kedudukan asesmen dalam penyusunan program kerja bimbingan dan konseling (2). Kedudukan asesmen dalam pemahaman diri siswa (3) Kedudukan asesmen dalam penetapan layanan bimbingan dan konseling. dan (4) Kedudukan asesmen dalam peminatan siswa pada kurikulum 2013.

Jelas bahwa kedudukan asesmen bagi konselor adalah hal sangat penting dalam pelaksanaan bimbingan dan konseling di sekolah sebagai alat ukur untuk memahami siswa, penyusunan dan pelaksanaan program kerja, dan melakukan evaluasi sehingga diharapkan siswa mendapat layanan professional guna pengembangan kearah perkembangan yang optimal.

\section{A. Pendahuluan}

Konselor sabagai tenaga professional harus bekerja secara professional, salah satunya bekerja dengan menggunakan alat pengumpul data yang tepat, akurat dan akuntabel dalam memahami dan mengenal siswa/klien dengan baik sesuai dengan permasalahannya. Merujuk pada Cronbach (1990) menyatakan hal yang sama, bahwa pengukuran sebagai suatu prosedur sistematik untuk mengobservasi dan mendeskripsikan perilaku (sampel perilaku) dengan menggunakan skala numerik atau kategori yang ditetapkan. Menurut Gultom (2013) Guru Bimbingan dan Konseling (Guru BK) harus mempunyai keterampilan untuk melaksanakan fungsi dan perannya sebagai guru BK profesional

Dalam mengenali siswa dengan mendalam baik pribadi maupun lingkungannya dalam kerangka memetakan lintasan perkembangan kepribadian (developmental trajectory) siswa dari keadaannya sekarang ke arah yang dikehendaki memerlukan alat ungkap atau instrumen. Memahami krakteristik siswa dapat menggunakan dua teknik pengumpulan data yaitu pertama menggunakan teknik asesmen non-tes seperti sosiometri, alat ungkap masalah umum atau daftar cek masalah dan alat 
ungkap masalah belajar atau skala penilaian, observasi, wawancara, dan studi dokumenter. Kedua menggunakan teknik asesmen tes psikologi seperti tes intelligensi, tes bakat, tes minat, tes kepribadian. Penggunaan asesmen ini dimaksudkan agar memperoleh data yang akurat yang hasilnya dapat dipercaya sehingga proses bantuan dan layanan yang diberikan sesuai dengan kebutuhan siswa, permasalahan siswa, keinginan siswa dan sesuai dengan karakteristik siswa itu sendiri.

Konselor sebagai jabatan profesi dalam bekerja tentu harus mampu menggunakan asesmen sebagai alat yang menunjang profesinya, seperti halnya dokter dalam bekerja dalam keperluan diagnosis pasien dengan menggunakan alat kerja seperti stateskop, gunting, jarum suntik, alat ukur tensi, thermometer. Demikian juga konselor sebagai jabatan profesi guna mendiagnosis siswa/klien guna mengetahi latar belakang kekuatan dan kelemahan serta permasalahan siswa tentunya juga harus memiliki alat ungkap yang dimaksud.

Kenyataan di lapangan masih ada guru BK/konselor yang tidak menggunakan hasil asesmen untuk keperlukan penyusunan program, penetapan layanan atau mungkin juga dalam keperluan pemahaman diri konseli juga dalam penempatan siswa pada program peminatan. Hal itu membuat guru BK/konselor sulit dalam penyelenggaraan bantuan dan layanan yang sesuai dengan permasalah klien. Agar bimbingan dan konseling terselengara dengan baik, konselor professional tentunya mengenal dan mampu menggunakan asesmen bimbingan dan konseling dalam bekerja (memberikan layanan). Dari beberapa paparan di atas penulis ingin membahas "Kedudukan Asesmen Bagi Konselor Profesional".

\section{B. PEMBAHASAN}

Tenaga-tenaga profesional dalam bekerja harus menggunakan alat yang sudah strandar (seperti yang sudah dijelaskan di atas). Konselor dalam bekerja juga menggunakan alat/instrumen guna memahami atau mendiagnoso permasalahan siswa seperti halnya dokter dalam memahami atau mendiagnosa penyakit pasiennya. Pembahasan mengkaji tentang kedudukan asesmen dalam pelaksanaan pekerjaan konselor profesional meliputi: (1). Kedudukan asesmen dalam penyusunan program kerja bimbingan dan konseling (2). Kedudukan asesmen dalam pemahaman diri siswa (3) Kedudukan asesmen dalam penetapan layanan bimbingan dan konseling. dan (4) Kedudukan asesmen dalam peminatan siswa

Data asesmen yang tersedia dari berbagai instrumen dapat berupa:

1. Sosiometri, diperoleh data tentang hubungan sosial siswa dalam hal mengungkap siswa yang menjadi bintang atau popular di kelasnya, keadaan kelas apakah kelas tersebut harmonis atau terpecah menjadi kelompok-kelompok dan data siswa yang melajusment (salah suai), atau terisolir dan tidak mempunyai teman dalam belajar dan kegiatan lainnya.

2. Alat Ungkap Masalah (AUM) Umum, diperoleh data tentang masalah umum siswa dalam hal keadaan jasman dan kesehatan, keuangan, keadaan keluarga, hubungan muda mudi, pembelajaran, dan penggunaan waktu senggang dan lain sebagainya

3. Alat Ungkap Masalah Belajar (AUM PTSDL) diperoleh data tentang mutu belajar dan masalah-masalah belajar misalnya berkenaan dengan keterampilan belajar, sarana belajar, keadaan diri siswa dalam belajar juga hal sekitar yang mempengaruhi belajar

4. Angket diperoleh data tentang minat jurusan siswa, keadaan pendidikan dan sosial ekonomi orangtua, aspirasi orangtua tentang pendidikan anaknya, latar belakang kesehatan siswa dan minat serta cita-cita masa depan siswa

5. Observasi diperoleh data tentang keadaan siswa dalam kegiatan belajar, pergaulan dan pemanfaatan waktu untuk kegiatan yang bermanfaat

6. Data dokumen yang tersedia berupa Daftar Leger Nilai, rekap absen siswa dan catatan tentang peristiwa di sekolah.

7. Self Esteem dan Locus of Control, diperoleh data tentang bagaimana gambaran konsep diri dan pengendalian diri siswa 
8. Hasil pengukuran psikologis berisi kemampuan, bakat, minat dan kepribadian siswa serta hasil penelusuran jurusan atau peminatan siswa.

Konselor profesional sudah sepatutnya mampu membuat, memilih, dan menggunakan serta menafsirkan hasil asesmen bimbingan dan konseling tersebut. Kedelapan jenis alat ukur/instrumen di atas bagi Konselor digunakan dalam bekerja agar memiliki data yang akurat sebagai dasar pertimbangan konselor dalam memberikan bantuan kepada siswa/klien.

\section{Kedudukan Asesmen dalam Penyusunan Program Bimbingan dan Konseling}

Berbagai hal di atas adalah berupa instrumen yang dapat menyediakan data yang berguna untuk penyusunan program kerja guru BK. Program kerja bimbingan dan konseling merupakan bagian utama yang harus dilakukan konselor sekolah. Pada zaman kurikulum 1975 pertama kalinya bimbingan dan konseling (bimbingan dan penyuluhan waktu itu) sebelum guru BK melaksanakan tugasnya diharuskan menyusun program. Penyusunan program diawali dengan study kelayakan dan rapat para guru BK untuk mendudukan apa yang sebaiknya materi dan isi program BK untuk pertahun. Sayangnya pada waktu guru BK hanya mempunyai program yang sama untuk semua guru BK dan semua tingkat kelas.

Study kelayakan untuk penyusunan program dewasa ini berdasarkan data autentik dengan menggunakan instrumen sebagai model asesmen dalam BK agar hasilnya dapat dipercaya sehingga penyusunan program sesuai dengan kebutuhan siswa. Hal ini merupakan hal penting yang harus diperhatikan para konselor profesional, menurut Ana Jumiawati (2014:1) penyusunan program sesuai dengan kebutuhan siswa berarti guru BK melakukan transformasi dalam berpikir dan bertindak supaya lebih bertanggung jawab dan bermakna dalam melaksanakan proses layanan di sekolah.

Hasil asesmen sebagai dasar pengembangan program layanan BK di sekolah. Menurut M. Ramli, dkk (2014:3) dapat berupa asesmen teknik non tes dan asesmen teknik tes yang meliputi:

(1) teknik observasi sebagai salah satu teknik mengungkap merekam data tingkah laku individu/siswa melalui proses pengamatan, hal ini bisa dilakukan dengan menggunakan daftar cek, catatan anegdot, fotofoto. (2) wawancara sebagai berguna untuk mengklarifikasi berbegai data (3) angket, sebagai salah satu alat yang dapat memberikan masukan tentang berbagai hal (4) dokumen berupa leger nilai, rekap absensi siswa yang berisi data tentang prestasi belajar siswa baik yang hasil belajarnya sudah tuntas ataupun yang belum tuntas dan harus mendapatkan remidi serta gambaran disiplin siswa dalam belajar. Teknik tes meliputi hasil pengukuran psikologi yang menguangkapkan tingkat kecerdasan siswa, kecenderungan bakat dan peminatan siswa dan minat serta kepribadian siswa.

Kesemua data hasil instrumen di atas sangat diperlukan untuk menyusun program BK, agar program BK tetap dalam keadaan up to date atau baru terus sesuai dengan kebutuhan siswa dan azas kekinian. Setiap saat siswa memiliki masalah dan pengembangan diri yang selalu berubah secara dinamis. Program yang baik sesuai dengan siklus dan perubahan siswa yang selalu berubah-ubah sesuai dengan kemajuan zaman, Makanya program disusun sesuai dengan kebutuhan dan kepentingan siswa. Program yang demikian akan menarik dan menyenangkan karena mampu mengikuti seluruh tugas perkembangan siswa dan permasalahannya. Menurut Prayitno (1997) syarat-syarat yang harus dipenuhi dalam menyusun program adalah sebagai berikut bahwa program harus:

a. Berdasarkan kebutuhan guna pengembangan peserta didik sesuai dengan kondisi pribadinya, serta jenjang dan jenis pendidikannya.

b. Lengkap dan menyeluruh, artinya memuat segenap fungsi bimbingan. Kelengkapan program ini disesuaikan dengan kebutuhan dan karakteristik siswa pada satua npendidikan yang bersangkutan.

c. Sistematik, dalam arti program disusun menurut urutan logis, tersingkronisasi dengan menghindari tumpang tindih yang tidak perlu serta dibagi-bagi secara logis. 
d. Terbuka dan luwes, artinya mudah menerima masukan untuk

pengembangan dan penyempurnaan tanpa harus merombak program itu secara menyeluruh.

e. Memungkinkan kerja sama dengan fihak yang terkait dalam rangka sebesar-besarnya memanfaatkan berbagai sumber dan kemudahan memanfaatkan berbagai sumber yang tersedia bagi kelancaran dan keberhasilan pelayanan BK.

f. Memungkinkan diselenggarakannya penilaian dan tindak lanjut untuk penyempurnaan program pada khususnya dan peningkatan keefektifan dan keefisienan penyelenggaraan program BK pada umumnya

Program bimbingan dan konseling yang dirumuskan berdasarkan data asesemen memungkinkan program layanan BK dapat dilaksanakan dengan baik, sesuai dengan latar belakang dan kebutuhan siswa. Upaya pencegahan, pengentasan dan pengembangan yang dilakukan juga sesuai dengan keinginan, harapan, permasalahan dan kebutuhan siswa.

\section{Kedudukan Asesmen dalam Pemahaman Diri Siswa}

Berbagai instrumen di atas dapat menyediakan data yang berguna untuk pemahaman diri bagi siswa baik dalam hal kemampuan, bakat, minat, cita-cita, juga keadaan kehidupan pribadi, sosial, belajar dan pengembangan arah karir siswa di masa depan.

Hasil asesmen mampu mengungkapkan keadaan diri pribadi siswa dalam hal; bergaul atau berteman, kegiatan belajar dan tipe-tipe belajar yang dimiliki, kemampuan yang dimiliki, bakatbakat dan kreativitas atau potensi yang perlu dikembangkan, minat yang mungkin dikembangkan, keseuaian cita-cita dengan kemampuan Cronbach (1990) mengatakan bahwa penggunaan tes dalam kegiatan pengukuran dimaksudkan untuk memajukan pemahaman diri. Syamsu Yusuf (1998) menyebutkan tujuan pengukuran atau asesmen untuk memperoleh data yang relevan, objektif, akurat dan konprehensif tentang kondisi siswa saat ini, mengetahui profil siswa secara utuh terutama dan hambatan belajar yang dihadapi, potensi yang dimiliki, kebutuhan-kebutuhan khususnya serta daya dukung lingkungan yang dibutuhkan siswa. Prayitno (2004) tujuan pengukuran psikologis bagi siswa bertujuan untuk menilai tingkah laku, kecakapan mental, dan karakteristik kepribadian siswa dalam rangka membantu siswa membuat keputusan.

Komalasari dkk. (2011) menjelaskan bahwa asesmen dalam bimbingan dan konseling mempunyai beberapa tujuan, yaitu:

a. Orientasi masalah, yaitu untuk membuat siswa mengenali dan menerima permasalahan yang dihadapinya, tidak mengingkari bahwa ia bermasalah

b. Identifikasi masalah, yaitu membantu baik bagi siswa maupun konselor dalam mengetahui masalah yang dihadapi siswa secara mendetil

c. Memilih alternatif solusi dari berbagai alternatif penyelesaian masalah yang dapat dilakukan oleh siswa

d. Pembuatan keputusan alternatif pemecahan masalah yang paling menguntungkan dengan memperhatikan konsekuensi paling kecil dari beberapa alternatif tersebut

e. Verifikasi untuk menilai apakah konseling telah berjalan efektif dan telah mengurangi beban masalah siswa atau belum

f. Mengembangkan cara siswa merespon (verbal dan/atau non verbal) pertanyaan-pertanyaan yang disampaikan oleh guru BK.

g. Melatih siswa untuk berpikir dalam upaya pemecahan masalah

h. Membentuk kemandirian siswa dalam berbagai masalah atau membentuk individu menjadi mandiri.

i. Melatih siswa mengemukakan apa yang dipikirkan dan apa yang dirasakan. melalui proses konseling.

j. Membentuk individu yang terbuka dalam berbagai hal, termasuk membuka diri dalam konseling

k. Membina kerjasama yang baik dalam memecahkan masalah yang dihadapi. 
1. Membelajarkan siswa untuk menilai terhadap cara melaksanakan keputusannya secara konsekuen.

Dari uarian di atas jelas bahwa tujuan dan fungsi asesmen mampu mengungkapkan keadaan diri pribadi siswa dalam hal mengungkapkan potensi atau kekuatan yang perlu dikembangkan, prestasi belajar yang harus dipelihara dan ditingkatkan, masalah yang dialami dan mengganggu kesuksesan belajar siswa yang harus dipecahkan, bentuk pergaulan yang perlu dikembangkan dan diperbaiki sehingga siswa berkembang secara optimal

\section{Kedudukan Asesmen dalam Penetapan Layanan Bimbingan dan Konseling}

Asesmen atau pengukuran adalah untuk mengetahui keadaan siswa pada saat tertentu (waktu dilakukan asesmen) baik potensi yang dimiliki maupun berbagai kelemahan yang dimiliki siswa yang menjadi dasar dalam pemberian layanan bimbingan dan konseling sehingga guru BK atau konselor dapat melakukan layanan intervensi yang tepat sesuai dengan latar belakang masalah dan kebutuhan. National Council on Measurement in Education [NCME],1999).menjelaskan bahwa melakukan kegiatan pengukuran adalah untuk memperoleh gambaran berbagai kondisi individu dan lingkungannya sebagai dasar pengembangan program layanan bimbingan dan konseling sesuai kebutuhan.

Berpedoman kepada hasil asesmen, dapat ditetapkan jenis layanan apa yang dibutuhkan siswa, dengan hasil asesmen juga dapat dirancang materi yang dibutuhkan dalam layanan yang akan diberikan. Misalnya dari hasil sosiometri terdapat 3 kelompok siswa yang klik dan 8 orang yang terisolir. Untuk siswa yang klik diberikan bantuan berupa bimbingan kelompok sedangkan yang terisolir diberikan bantuan melalui jenis layanan konseling perorangan (individual). Data AUM Umum yang dilaksanakan Ainul Mardiah NIM 1200543 di kelas X SMAN 1 Padang tahun 2015 terugkap bahwa sebanyak 22 orang siswa tidak memiliki pengetahuan tentang bakat, pekerjaan yang akan dijabat, hal ini sudah barang tentu menjadi perhatian guru BK di sekolah tersebut dan apa layanan yang tepat diberikan untuk siswa tersebut? Jawabnya pertama yang harus diungkap adalah bakat dan potensi yang dimiliki siswa melalui asesmen psikologis atau melakukan analisis dokumen tes jika sekolah tersebut sudah melakukan tes peminatan. Hal lain yang juga ditemui bahwa sebanyak 26 orang dari 32 siswa masih menghawatirkan nilai rendah dalam ujian, ulangan dan tugas-tugas. Apa jenis layanan yang harus diberikan oleh guru BK? Karena lebih $81 \%$ siswa yang bermasalah dalam hal ini maka yang paling tepat digunakan adalah konseling format klasikal, tentu dengan materi layanan cara belajar efektif dalam mempersiapkan siswa menghadapi ujian atau kiat-kiat mengerjakan tugas.

Bagaimana dengan hasil AUM Belajar (PTSDL) di kelas X SMAN 1 Padang tersebut terungkap bahwa 22 orang siswa tidak percaya diri dalam kegiatan belajar di kelas, 26 orang tidak memiliki catatan dalam belajar, 22 orang tidak mempunyai semangat yang tinggi untuk semua mata pelajaran. Apakah keadaan yang demikaian mau dibiarkan saja oleh guru BK. Agar semua siswa sukses guru BK harus mencarikan solusinya masalah ini melalui kegiatan atau layanan konseling yang tepat sesuai dengan permasalahan siswa tersebut.

Paparan di atas mengisyaratkan bahwa hasil asesmen memberikan masukan dalam menyusun program layanan, seperti program layanan konseling format klasikal, konseling individual, dan bimbingan/konseling kelompok secara terjadual tanpa tumpang tindih antara program perjenjang dengan program antar kelas di sekolah. Pertanyaannya, Apakah sekolah telah memiliki alat, instrumen bimbingan dan konseling sebagai alat ukur dalam menyelenggarakan layanan konseling professional? Apakah telah melaksanakan asesmen atau pengukuran sebelum menyusun program kerja guru BK? Apakah penetapan layanan yang akan diberikan pada siswa adalah hasil asesemen? Semuanya tentu terpulang kepada guru BK yang bersangkutan, hal ini bisa terlaksana tentunya oleh guru BK yang mempunyai komitmen dan tanggungjawab. 


\section{Kedudukan Asesmen dalam Peminatan Siswa pada Kurikulum 2013}

Pada kurikulum 2013 ada beberapa bentuk pemintana siswa seperti yang terlihat pada tabel berikut

\begin{tabular}{|c|c|c|c|}
\hline $\begin{array}{c}\text { Tingkat } \\
\text { Peminatan }\end{array}$ & Peminatan Akademik & Peminatan Kejuruan & $\begin{array}{c}\text { Peminatan Studi } \\
\text { Lanjutan }\end{array}$ \\
\hline $\begin{array}{l}\text { 1. Peminatan } \\
\text { di SD/MI }\end{array}$ & $\begin{array}{l}\text { Meminati semua mata } \\
\text { pelajaran }\end{array}$ & $\begin{array}{l}\text { Pemahaman awal } \\
\text { tentang pekerjaan/karir }\end{array}$ & SMP/MTs \\
\hline $\begin{array}{l}\text { 2. Peminatan } \\
\text { di SMP/MTs }\end{array}$ & $\begin{array}{l}\text { Meminati semua mata } \\
\text { pelajaran }\end{array}$ & $\begin{array}{l}\text { Pemahaman tentang } \\
\text { pekerjaan/karir dan } \\
\text { kemungkinan bekerja }\end{array}$ & SMA/MA/SMK \\
\hline $\begin{array}{l}\text { 3. Peminatan } \\
\text { di SMA/MA }\end{array}$ & $\begin{array}{l}\text { Meminati kelompok } \\
\text { mapel, mapel pilihan, } \\
\text { lintas minat, dan } \\
\text { pendalaman minat. }\end{array}$ & $\begin{array}{l}\text { Pemahaman definitif } \\
\text { tentang pekerjaan/karir } \\
\text { dan arah pelaksanaan } \\
\text { pekerjaan/karir }\end{array}$ & $\begin{array}{l}\text { Program Khusus } \\
\text { bidang studi } \\
\text { IPA/IPS/BHS }\end{array}$ \\
\hline $\begin{array}{l}\text { 4. Peminatan } \\
\text { di SMK }\end{array}$ & $\begin{array}{l}\text { Meminati mapel } \\
\text { program keahlian, } \\
\text { mapel pilihan program } \\
\text { keahlian, lintas minatl } \\
\text { program keahlian, dan } \\
\text { pendalaman minat } \\
\text { program keahlian }\end{array}$ & $\begin{array}{l}\text { Arah definitif tentang } \\
\text { pelaksanaan } \\
\text { pekerjaan/karir (jenjang } \\
\text { operator) }\end{array}$ & $\begin{array}{l}\text { Prodi Khusus } \\
\text { Bidang Kejuruan }\end{array}$ \\
\hline $\begin{array}{l}\text { 5. Peminatan } \\
\text { Pasca SMA/ } \\
\text { MA/SMK }\end{array}$ & $\begin{array}{l}\text { Bekerja atau kuliah } \\
\text { sesuai dengan pilihan } \\
\text { mapel, lintas minat dan } \\
\text { pendalaman minat di } \\
\text { SLTA }\end{array}$ & $\begin{array}{l}\text { Arah pekerjaan/karir } \\
\text { (jenjang teknisi/analis, } \\
\text { profesi, atau ahli) }\end{array}$ & $\begin{array}{l}\text { Fakultas dan } \\
\text { Prodi di PT }\end{array}$ \\
\hline
\end{tabular}

Layanan peminatan memerlukan asesmen guna mengumpulkan berbagai data dari siswa dan orangtua guna mendukung pilihan peminatannya agar pemilihan peminatan lebih mantap dan bermakna. Data yang berkaitan dengan peminatan dapat menggunakan teknik non tes. Teknik non tes dapat diyakini sebagai teknik untuk memperoleh data pokok untuk penetapan peminatan siswa. Dan bagi sekolah yang mempunyai daya dukung dana dan tenaga dan mengharapkan data lebih dapat menggunakan teknik tes untuk mendeteksi potensi peminatan siswa.Data yang diperlukan dapat berupa:

a. Data hasil belajar siswa kelas VII. VII, IX dengan merata-ratakan nilai ciri khas jurusan peminatan siswa yang dikehendali.

b. Data hasil belajar digabung dengan nilai ujian nasional (UN) dikaitkan dengan peminatan siswa

c. Minat studi lanjutan dan aspirasi orangtua siswa

d. Data fasilitas, harapan dan cita-cita karir siswa dan keadaan ekonomi orangtua

e. Data hasil observasi guru atau rekomendasi guru pada sekolah sebelumnya (SMP). 
Sedangkan jika ingin data lebih dapat dengan menggunakan tes bakat dapat digunakan tes berupa;

a. Tes Inteligensi

b. Tes Pemahaman Verbal

c. Tes Kemampuan Numerikal

d. Tes Kemampuan Skolastik

e. Tes Kemampuan Kerja Klerikal

f. Tes Kemampuan Hubungan Ruang

g. Tes Kemampuan Mekanikal

h. Tes Pemakaian Bahasa

i. Dan tes lain yang sejenis

Dalam kurikulum 2013 peminatan akademik diselenggarakan dalam 3 bentuk. Pertama peminatan mata pelajaran, kedua lintas minat dan yang ketiga pendalaman minat. Kesemuanya tentu memerlukan data agar pemilihan minat siswa sesuai dengan bakat, minat dan cita-cita siswa serta prestasi belajar yang diharapkan.

Langkah-langkah yang harus dilakukan dalam peminatan, Kemendikbud 2014 yaitu 1. Pengumpulan data yang mendukung peminatan siswa, di sini diperlukan asesmen yang mampu mengungkap data berupa potensi dan prestasi siswa yang akurat dan akuntabel, data daya tampung sekolah dan kecukupan guru pengampu mata pelajaran. 2. Informasi peminatan yang berisi informasi tentang jenjang dan jenis sekolah lanjutan, program dan jurusan yang tersedia, pengenal perguruan tinggi, syarat-syarat masuk dan prospek pekerjaan di masa depan. 3 . Identifikasi dan pemantapan peminatan berisi pemahaman diri, kemampuan, bakat minat dan hasil belajar, pemahaman peminatan mata pelajaran, lintas minat dan pendalaman minat. 4 . Penyesuaian peminatan, jika ada siswa yang ragu dalam pemilihan peminatan, dengan melakukan konseling terhadap siswa yang bersangkutan

Tepat tidaknya pemilihan peminatan siswa akan sangat dipengaruhi oleh akurasi data berupa kemampuan, prestasi siswa, minat siswa, aspirasi orang tua dan ekonomi orangtua siswa yang bersangkutan.

\section{SIMPULAN}

Berdasarkan pembahasan di atas dapat disimpulkan bahwa kedudukan asesmen bagi konselor professional adalah sebagai berikut:

1. Penyusunan program berdasarkan hasil asesmen sehingga program disusun berdasarkan analisis kebutuhan siswa.

2. Proses pemahaman diri siswa (konseli/klien) merujuk kepada hasil asesmen untuk mengetahui kekuatan siswa berupa potensi-potensi dan kelemahannya berupa permasalahan yang perlu menjadi perhatian konselor (guru BK)

3. Rencana dan pelaksanaan layanan akan terasa bermanfaat jika sesuai dengan hasil asesmen sehingga pengembangan diri siswa sesuai dengan materi, jenis dan bentuk layanan

4. Peminatan siswa berdasarkan data yang lengkap, akurat dan akuntabel akan memotivasi siswa belajar dengan baik, sungguh-sungguh karena sesuai dengan kemampuan, bakat, minat dan cita-citanya.

\section{E. Sumber}

Ana Jumiati. 2014. Implementasi Kurikulum 2013 Dalam Bimbingan Dan Konseling, Blog ana jumiati Ainul Mardiah. 2015. Pelaksanaan PLBK-S di SMAN 1 Padang. Padang: Jurusan BK FIP UNP Cronbach, L.J. (1990). Essentials of psychological testing (5th ed.). New York: Harper Collins M. Ramli. 2016. Pendekatan Konseling. Jakarta: Kemendikbud Dimyati dan Mujiono. (2002). Psikologi Pendidikan. Jakarta: Rineka Cipta. Komalasari, Gantina., Wahyuni, Eka., dan Karsih. (2011). Asesmen teknik non tes dalam perpektif BK komprehensif. Jakarta: PT. Indeks 
Komalasari, Gantina. 2016. Konsep Dasar Assesmen dan Kedudukannya dalam BK.Jakarta: BK FIP UNJ

Mendikbud. 2014. Implementasi Kurikulum 2013. Jakarta: Kemendikbud

Mendikbud. 2014. Pengeloloan Bimbingan dan Konseling dalam implementasi Kurikulum 2013. Jakarta: Kemendikbud

Mendikbud. 2014. Asesmen Pemantapan Peminatan Peserta Didik. Jakarta: Kemendikbud

Mendikbud. 2014. Praktik Layanan Bimbingan dan Konseling. Jakarta: Kemendikbud

Prayitno (1997). Dasar Teori dan Proksis PendidikanJakarta: Gramedia/Grasindo

Prayitno. 2004. Layanan Bimbingan dan Konseling. Jurusan Bimbingan dan Konseling FIP. UNP Syawal Gultom. 2013. Kurikulum 2013.Jakarta: Depdikbud

Syamsu Yusuf LN. (1998). Model Bimbingan dan Konseling dengan Pendekatan Ekologis. Disertasi Bandung : PPs UPI 